\title{
DETERMINATION OF LEADERSHIP STYLE, COMMUNICATION, AND WORK ENVIRONMENT ON EMPLOYEE PERFORMANCE WITH ORGANIZATIONAL CULTURE AS INTERVENING VARIABLES IN BANK MANDIRI IN BATAM CITY
}

\author{
Esra Erita Sari Silalahi ${ }^{1}$, Chablullah Wibisono ${ }^{2}$ and Joko Rizkie Widokarti ${ }^{3}$ \\ ${ }^{1}$ Master of Human Resources Management Program - Open University, \\ ${ }^{2}$ Sharia Economics Professor of the Faculty of Economics at Batam University, \\ ${ }^{3}$ Post-Graduate Program Open University,
}

DOI: http://dx.doi.org/10.38193/IJRCMS.2021.3408

\begin{abstract}
This study analyzes the variables of leadership style, communication, and work environment on employee performance either directly or mediated by organizational culture. The research analysis technique uses path analysis with Structural Equation Modeling_PLS, where the sample used is 90 leaders of Bank Mandiri Batam Area using the census method. The study results obtained significant values of $p$ values less than 0.05 , namely the influence of leadership style and work environment on organizational culture, work environment, and organizational culture variables on performance. While communication on organizational culture is not significant, leadership style and work environment on performance do not have a significant effect. The results of the indirect influence obtained a significant value on the variables of leadership style and work environment on performance through an organizational culture of less than 0.05 , meaning that organizational culture mediates the influence of leadership style and work environment on performance. While the significance value of the communication variable on performance through organizational culture is more than 0.05 , meaning that organizational culture does not mediate the effect of communication on performance. Communication on organizational culture, as well as leadership style and work environment on performance.
\end{abstract}

KEYWORDS: Leadership Style, Communication, Work Environment, Employee Performance, Culture Organization

\section{PRELIMINARY}

Banking is an inseparable part of the economy of a country. Where its human resources become the basis for the development of the bank's operations. PT. Bank Mandiri (Persero) Tbk. is one of the state-owned banks with high employee standards. The high standard of employees is an obligation to improve the performance of employees in particular and the company as a whole. Organizational culture will make organizational members more emotionally attached to the organization and tend to 
be more helpful to colleagues and superiors in completing tasks, preventing problems at work, encouraging and strengthening, and helping the organization. Intact by tolerating less than ideal situations at work, concerned with the continuity of the organization,

The quality of the leader is often considered the most critical factor in the success or failure of the organization. The success or failure of the leader, the role of the leader, is so vital that the issue of leaders has attracted the attention of researchers in the field of organizational behavior (Prihayani, 2017: 43). The role of a leader in influencing his subordinates is vital for the progress of the organization. According to Koesmino in Khairizah et al. (2017), a leader in the organization is needed to bring the organization to the goals that have been set. Leaders usually apply certain leadership styles to influence the performance of their subordinates. Leadership style is a leader's behavior that a person uses when he wants to influence others.

For employees, open communication can allow employees to provide input for the company, feel involved in the work, and be happier in carrying out their duties. This will provide satisfaction for both parties to create a good working relationship. Good communication can be the proper means of improving employee performance. Through communication, employees can ask for instructions from their superiors regarding the implementation of work. In addition, good communication between fellow employees will also make it easier for employees to work together to carry out their duties.

The work environment is everything around the workers that can affect the workability of employees in carrying out their duties so that they will obtain maximum work results. An individual who is in his work environment will constantly interact with co-workers and with superiors. The work environment is an environment where employees carry out their daily work. A conducive work environment provides a sense of security and allows employees to work optimally.

Banking is an inseparable part of the economy of a country. Where its human resources become the basis for the development of the bank's operations. PT. Bank Mandiri (Persero) Tbk. is one of the state-owned banks with high employee standards. The high standard of employees is an obligation to improve the performance of employees in particular and the company as a whole. Organizational culture will make organizational members more emotionally attached to the organization and tend to be more helpful to colleagues and superiors in completing tasks, preventing problems at work, encouraging and strengthening, and helping the organization. Intact by tolerating less than ideal situations at work, concerned with the continuity of the organization,

The quality of the leader is often considered the most critical factor in the success or failure of the organization. The success or failure of the leader, the role of the leader, is so vital that the issue of leaders has attracted the attention of researchers in the field of organizational behavior (Prihayani, 
2017: 43). The role of a leader in influencing his subordinates is vital for the progress of the organization. According to Koesmino in Khairizah et al. (2017), a leader in the organization is needed to bring the organization to the goals that have been set. Leaders usually apply certain leadership styles to influence the performance of their subordinates. Leadership style is a leader's behavior that a person uses when he wants to influence others.

For employees, open communication can allow employees to provide input for the company, feel involved in the work, and be happier in carrying out their duties. This will provide satisfaction for both parties to create a good working relationship. Good communication can be the proper means of improving employee performance. Through communication, employees can ask for instructions from their superiors regarding the implementation of work. In addition, good communication between fellow employees will also make it easier for employees to work together to carry out their duties.

The work environment is everything around the workers that can affect the workability of employees in carrying out their duties so that they will obtain maximum work results. An individual who is in his work environment will constantly interact with co-workers and with superiors. The work environment is an environment where employees carry out their daily work. A conducive work environment provides a sense of security and allows employees to work optimally.

\section{LITERATURE REVIEW}

\section{Employee Performance}

Performance or work performance is the result or level of success of a person as a whole during a specific period in carrying out tasks compared to various possibilities, such as work standards, targets or targets, or performance that have been determined in advance and mutually agreed upon. (Rivai, 2018).

\section{Leadership Style}

Leadership is the process of understanding what people do together to understand and are willing to do it (Yulk, 2015). Leadership in organizations is directed to influence the people they lead, to want to act as expected or directed by others who lead them (Sutikno, 2014).

\section{Communication}

Communication is the transfer of information and understanding from one person to another (Mangkunegara, 2017). Communication plays a vital role in expediting the company's activities; this can be seen from the following:(Mulyana, 2015):

1. By communicating management functions, namely planning, organizing, directing, and supervising. 
2. Increase enthusiasm and work motivation.

3. By using communication as a means of coordination and control, leaders can find out the state of the field they are tasked with.

4. Create a sense of solidarity and loyalty between subordinates and superiors, subordinates and subordinates, and between fellow superiors due to clear and steady supervision.

5. All parts of the organization can find out the policies, regulations, and provisions that the leadership has set with communication.

\section{Work environment}

The work environment includes everything from parking facilities outside the company building, the location and design of the building, to the amount of light and sound that hits a person's work desk or workspace, or workspace. (Munandar, 2015). The work environment is an essential component in employees doing work activities (Rahmawati, Swasto, \& Prasetya, 2014)

\section{Organizational culture}

Organizational culture is a belief, attitude, and values generally held, which arise in the organization; put it more simply, culture is the way we do things here (Sedarmayanti, 2018). Organizational culture is a basis in the organization used as the basis for employees or employees to behave.

\section{Conceptual Framework}

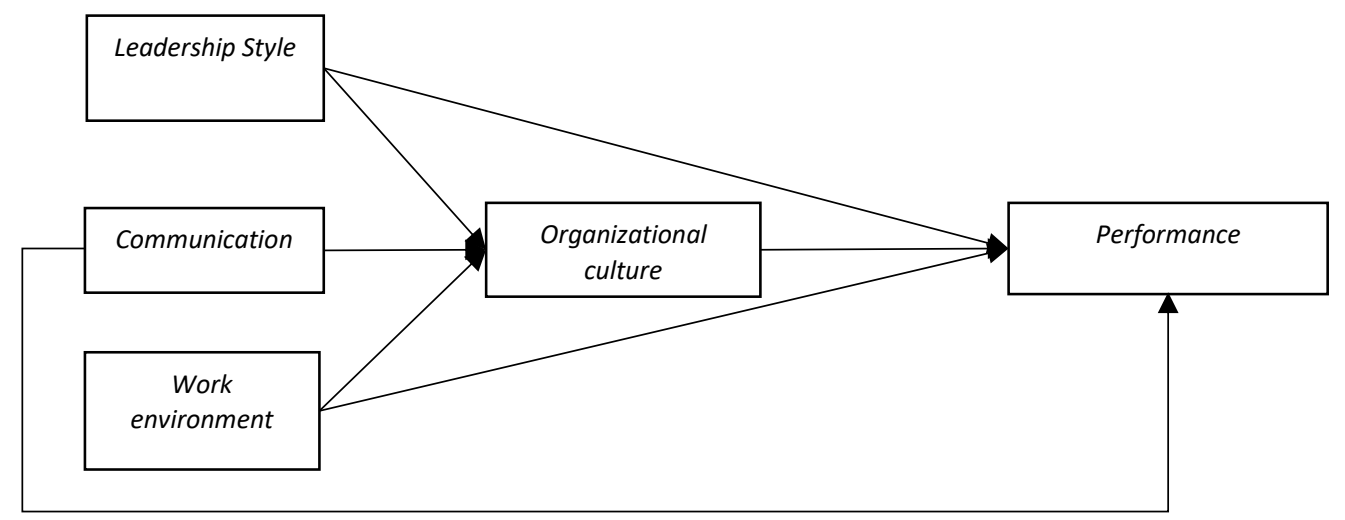

\section{Picture. 1. Research Model}

The research hypothesis is presented as follows: 
H1: Leadership style has an effect on organizational culture at Bank Mandiri Batam City.

$\mathrm{H} 2$ : Communication affects organizational culture at Bank Mandiri Batam City.

H3: Work environment influences organizational culture at Bank Mandiri Batam City.

H4: Leadership style has an effect on employee performance at Bank Mandiri Batam City.

H5: Communication has an effect on employee performance at Bank Mandiri Batam City.

H6: The work environment affects the performance of employees at Bank Mandiri Batam City.

H7: Organizational culture affects employee performance at Bank Mandiri Batam City.

H8: Leadership style affects employee performance through organizational culture at Bank Mandiri Batam City.

H9: Communication affects employee performance through organizational culture at Bank Mandiri Batam City.

H10: The work environment affects employee performance through organizational culture at Bank Mandiri Batam City.

\section{RESEARCH METHODOLOGY}

\section{Types of research}

This research is quantitative research with an associative approach. According to Russiadi et al. (2014), associative research aims to determine the degree of relationship and pattern/form of influence between two or more variables. This study builds conclusions that function to explain, predict, and control a symptom.

\section{Data sources and types.}

This study uses primary data in questionnaires filled out by the leadership of Bank Mandiri Branches in the Batam Region. It utilizes secondary data in data collected from various sources such as the internet, company HRD, and other sources related to research.

\section{Population and Sample}

The research population is all employees of the leadership of Bank Mandiri Batam Area, totaling 90 people. The census model determined the number of samples in this study. Sampling in the study was carried out by the saturated sample method, where the entire population was used as the research sample.

\section{RESEARCH RESULT \\ Outer Model}

The results of the study based on the loading factor value are as follows: 


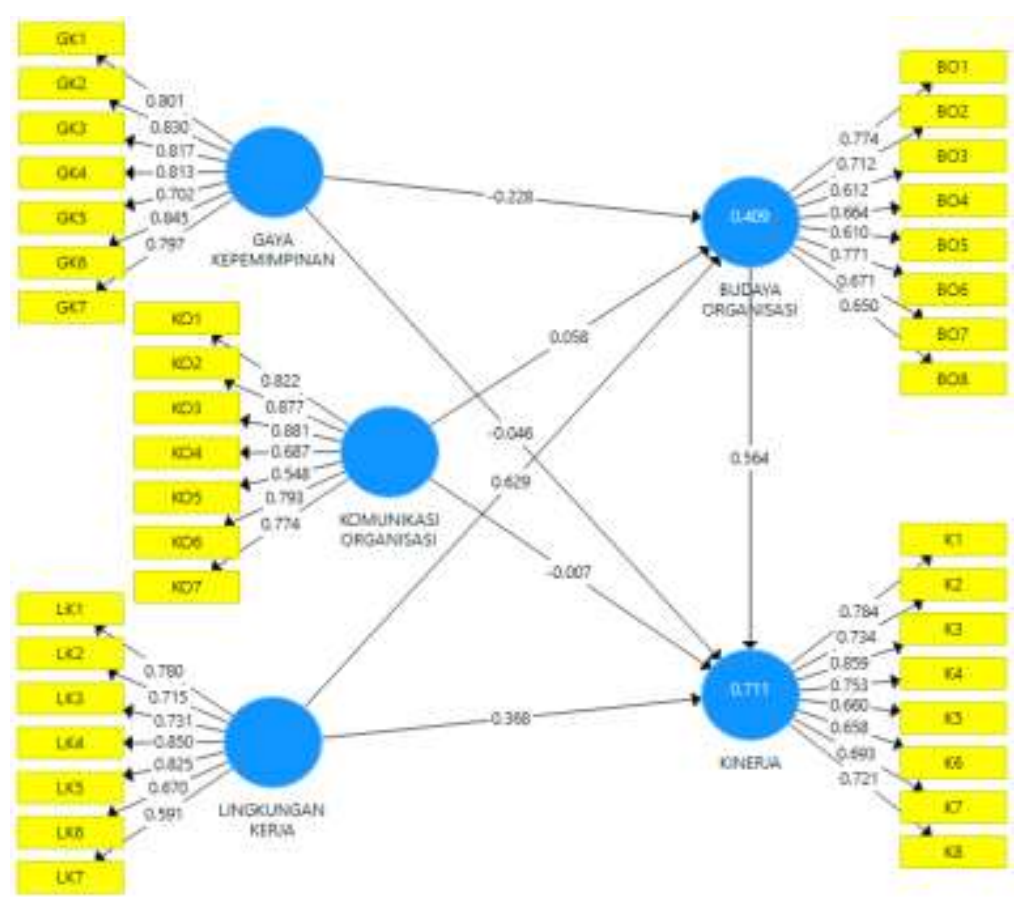

Fig.2. Loading Factor

Fig.2. Loading FactorBased on the picture above, it is known that the overall value of the loading factor in this study is more than 0.5 , meaning that all questionnaire items have met the requirements. Meanwhile, the research composite reliability value has exceeded 0.7. This is evidenced in the following table:

Table.1. Composite Reliability

\begin{tabular}{|l|l|c|}
\hline No & \multicolumn{1}{|c|}{ Variable } & Composite Reliability \\
\hline 1 & Leadership Style & 0.926 \\
\hline 2 & $\begin{array}{l}\text { Organizational } \\
\text { Communication }\end{array}$ & 0.912 \\
\hline 3 & Work environment & 0.894 \\
\hline 4 & Organizational culture & 0.876 \\
\hline 5 & Performance & 0.903 \\
\hline
\end{tabular}

Meanwhile, the Average Variance Extracted (AVE) value is described as follows: 
Table.2. Average Variance Extracted (AVE)

\begin{tabular}{|l|l|c|}
\hline No & \multicolumn{1}{|c|}{ Variable } & $\begin{array}{l}\text { Average } \\
\text { Extracted }\end{array}$ \\
\hline 1 & Leadership Style & 0.643 \\
\hline 2 & $\begin{array}{l}\text { Organizational } \\
\text { Communication }\end{array}$ & 0.603 \\
\hline 3 & Work environment & 0.551 \\
\hline 4 & Organizational culture & 0.504 \\
\hline 5 & Performance & 0.541 \\
\hline
\end{tabular}

The AVE value of each construct in the final model has reached a value $>0.5$. The proposed structural equation model has met the convergent validity criteria.

\section{Inner Model}

the value of R-Square (R2) on the variables based on the measurement results is shown in the following table:

Table 3. R Square

\begin{tabular}{|l|l|}
\hline & R Square \\
\hline Organizational culture & 0.409 \\
\hline Performance & 0.711 \\
\hline
\end{tabular}

The R Square value for the organizational culture variable is 0.409 ; this means that the percentage of the influence of leadership style, organizational communication, and work environment on organizational culture is $40.9 \%$, which means it is included in the Moderate category and the R Square value for the performance variable is $40.9 \%$. 0.711 , this means that the influence of leadership style, organizational communication, environment, and organizational culture on performance is $71.1 \%$, which means it is included in the Substantial (Strong) category.

, the adjusted R2 is 0.849, which means that variations from Zscore can explain $84.9 \%$ of employee performance variations: Work Motivation, Zscore: Locus of Control, Zscore: Organizational Commitment, AbsX1- Z, AbsX2-Z, AbsX3-Z. In contrast, the rest15.1\%, is influenced by other factors which are not examined in this model. The standard error of estimate (SEE) is 2.258, indicating that the smaller the SEE value will make the regression model more precise in predicting the dependent variable.

\section{Live Effect Test}

The results of the direct influence test are as follows: 


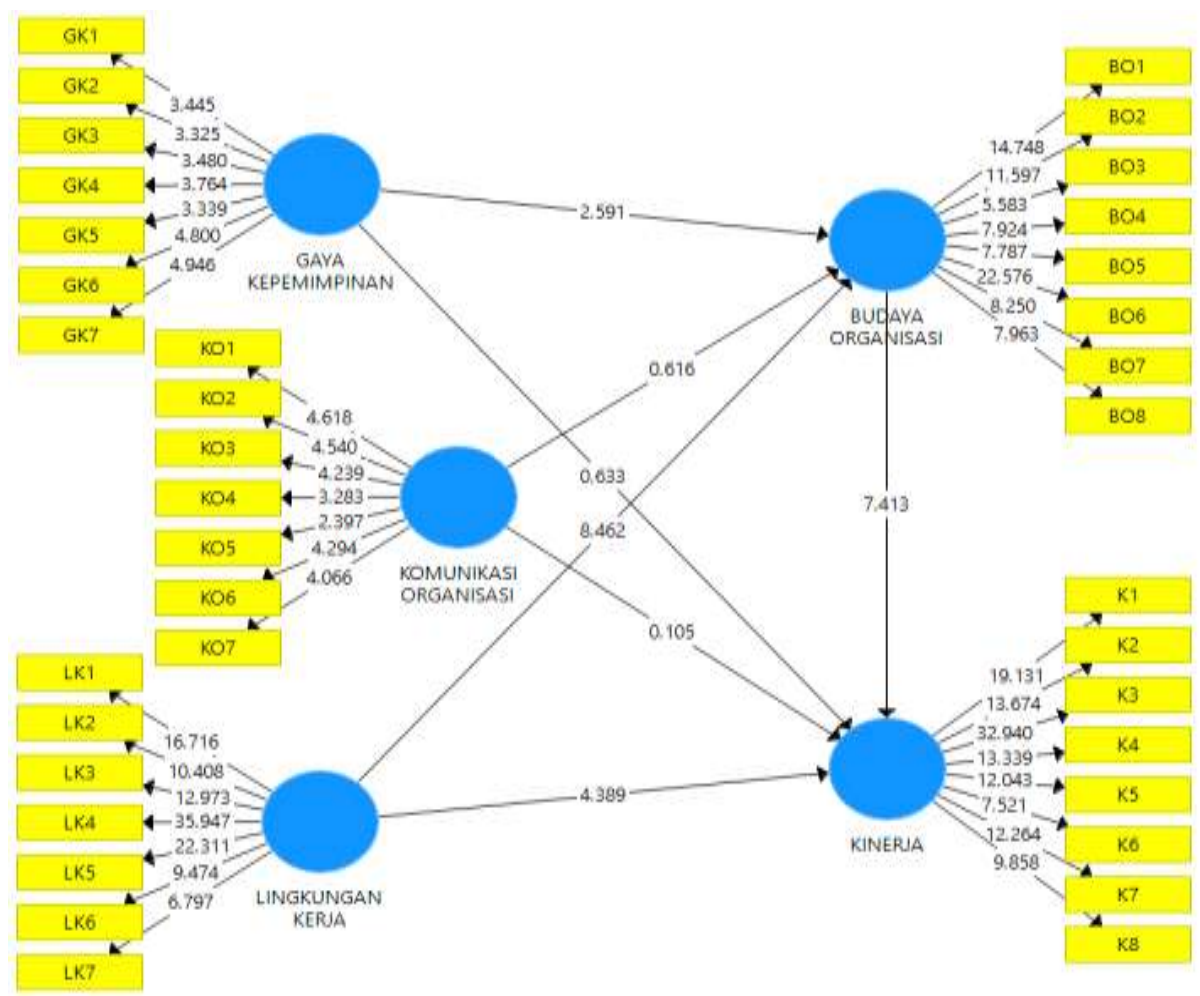

Fig.3. Path Coefficient between Research Variables

Table.4. Path Coefficients

\begin{tabular}{|l|c|c|c|c|c|}
\hline & $\begin{array}{c}\text { Original } \\
\text { Sample } \\
(\mathbf{O})\end{array}$ & $\begin{array}{c}\text { Sample } \\
\text { Mean } \\
(\mathbf{M})\end{array}$ & $\begin{array}{c}\text { Standard } \\
\text { Deviation } \\
(\mathbf{S T D E V})\end{array}$ & $\begin{array}{c}\text { T Statistics } \\
(\mathbf{O} / \mathbf{S T D E} \\
\mathbf{V})\end{array}$ & $\begin{array}{c}\mathbf{P} \\
\text { Values }\end{array}$ \\
\hline $\begin{array}{l}\text { Leadership Style } \rightarrow \\
\text { Organizational Culture }\end{array}$ & -0.228 & 0.232 & 0.088 & 2,591 & 0.010 \\
\hline $\begin{array}{l}\text { Organizational } \\
\text { Communication } \rightarrow \\
\text { Organizational Culture }\end{array}$ & 0.058 & 0.039 & 0.094 & 0.616 & 0.538 \\
\hline $\begin{array}{l}\text { Work Environment } \rightarrow \\
\text { Organizational Culture }\end{array}$ & 0.629 & 0.624 & 0.074 & 8,462 & 0.000 \\
\hline $\begin{array}{l}\text { Leadership Style } \rightarrow \\
\text { Performance }\end{array}$ & -0.046 & -0.047 & 0.073 & 0.633 & 0.527 \\
\hline
\end{tabular}


ISSN 2582-2292

Vol. 3, No. 04 July-Aug; 2021

\begin{tabular}{|l|c|c|c|c|c|}
\hline $\begin{array}{l}\text { Organizational } \\
\text { Communication } \rightarrow \\
\text { Performance }\end{array}$ & -0.007 & -0.014 & 0.069 & 0.105 & 0.916 \\
\hline $\begin{array}{l}\text { Work Environment } \rightarrow \\
\text { Performance }\end{array}$ & 0.368 & 0.364 & 0.084 & 4.389 & 0.000 \\
\hline $\begin{array}{l}\text { Organizational Culture } \rightarrow \\
\text { Performance }\end{array}$ & 0.564 & 0.564 & 0.076 & 7,413 & 0.000 \\
\hline
\end{tabular}

Based on the table above, a significant p-value is less than 0.05 , namely the influence of leadership style and work environment on organizational culture, work environment, and organizational culture variables on performance. While communication on organizational culture is not significant, leadership style and work environment on performance have no significant effect.

While the results of indirect influence are as follows:

Table. 5. Indirect Effect

\begin{tabular}{|l|l|l|l|l|l|}
\hline & $\begin{array}{l}\text { Original } \\
\text { Sample } \\
(\mathbf{O})\end{array}$ & $\begin{array}{l}\text { Sample } \\
\text { Mean } \\
(\mathbf{M})\end{array}$ & $\begin{array}{l}\text { Standard } \\
\text { Deviatio } \\
\mathbf{n} \\
(\mathbf{S T D E V})\end{array}$ & $\begin{array}{l}\text { T Statistics } \\
(\mid \mathbf{O} / \mathbf{S T D E V})\end{array}$ & $\begin{array}{l}\mathbf{P} \\
\text { Value } \\
\mathbf{s}\end{array}$ \\
\hline $\begin{array}{l}\text { Leadership Style } \rightarrow \\
\text { Organizational Culture } \rightarrow \\
\text { Performance }\end{array}$ & -0.128 & -0.131 & 0.054 & 2,396 & 0.017 \\
\hline $\begin{array}{l}\text { Organizational } \\
\text { Communication } \rightarrow \\
\text { Organizational Culture } \rightarrow \\
\text { Performance }\end{array}$ & 0.033 & 0.021 & 0.054 & 0.599 & 0.549 \\
\hline $\begin{array}{l}\text { Work Environment } \rightarrow \\
\text { Organizational Culture } \rightarrow \\
\text { Performance }\end{array}$ & 0.354 & 0.350 & 0.054 & 6.544 & 0.000 \\
\hline
\end{tabular}

The results of the indirect effect obtained a significant value on the variables of leadership style and work environment on performance through an organizational culture of less than 0.05 , meaning that organizational culture mediates the influence of leadership style and work environment on performance. While the significance value of the communication variable on performance through organizational culture is more than 0.05 , meaning that organizational culture does not mediate the effect of communication on performance. 
Vol. 3, No. 04 July-Aug; 2021

\section{BIBLIOGRAPHY}

Aspan, H., Wahyuni, E., Effendy, S., Bahri, S., Rambe, M., \& Saksono, F. (2019). The Moderating Effect of Personality on Organizational Citizenship Behavior: the Case of University Lecturers. International Journal of Recent Technology and Engineering (IJRTE), Vol. 8 No. 2S, 412-416.

Mangkunegara, AA (2017). Company Human Resources Management. Bandung: Rosdakarya Youth. Mulyana, I. (2015). Human Resources. Jakarta: Salemba Empat.

Munandar. (2015). Human Resource Management. Bandung: Alphabeta.

Rahmawati, NP, Swasto, B., \& Prasetya, A. (2014). The Effect of Work Environment on Employee Performance (Study on Employees of the Pratama North Malang Tax Service Office). Journal of Business Administration (JAB) Vol. 8 No. 2, 1-9.

Rivai, V. (2018). Human Resource Management for Companies. Jakarta: Raja Grafindo Persada.

Sedarmayanti. (2018). Human Resource Management Bureaucratic Reform and Civil Servant Management. Bandung: Refika Aditama.

Sutikno. (2014). Leaders and Leadership. Lombok: Holistica.

Wahyuni, E., Fachrudin, K., \& Silalahi, A. (2019). An Empirical Study on Women's Financial Behavior: Case Study of Female Postgraduate Students in Medan, Indonesia. International Journal of Research Culture Society, 155-159.

Wibisono, C., \& Yanti, S. (2020). Effect of Work Motivation, Competence, and Discipline of Performance Through Teacher Satisfaction. International Journal of Research In Commerce and Management Studies.

Wibisono, C., Widia, E., Irwansyah, H., \& Faizah, A. (2020). Effects of Regional Tax, Retribution, and Zakat Maslahah Through Local Revenue/Effectos del impuesto regional, retribution y Zakat Maslahah a traves de los ingresos locales. Utopía y Praxis Latinoamericana 25 (S6), 103-114.

Yulk, G. (2015). Leadership in Organizations. Jakarta: Index. 